Prepared in cooperation with the Louisiana Department of Transportation and Development

\title{
Water Resources of Union Parish, Louisiana
}

\section{Introduction}

Information concerning the availability, use, and quality of water in Union Parish, Louisiana (fig. 1), is critical for proper water-supply management. The purpose of this fact sheet is to present information that can be used by water managers, parish residents, and others for stewardship of this vital resource. In 2014, about 4.88 million gallons per day (Mgal/d) of water were withdrawn in Union Parish: $4.70 \mathrm{Mgal} / \mathrm{d}$ from groundwater sources and $0.18 \mathrm{Mgal} / \mathrm{d}$ from surface-water sources ${ }^{1}$ (table 1).

\section{Groundwater Resources}

The primary freshwater-bearing aquifer in Union Parish is the Sparta aquifer. The Sparta aquifer underlies the Cook Mountain aquifer, which is present in thin lenses of fine sands within the Cook Mountain confining unit and can supply limited amounts of freshwater (Snider and others, 1972). The Cook Mountain aquifer is not discussed further in this publication. The Cockfield aquifer and, in the northeastern part of Union Parish, the Upland terrace
Withdrawals for public-supply use accounted for about 89 percent (4.36 Mgal/d) of the total water withdrawn (table 2). Other categories of use included industrial, rural domestic, livestock, rice irrigation, and general irrigation. Water-use data collected at 5-year intervals from 1960 to 2010 and again in 2014 indicated that water withdrawals peaked in 2000 at about $8.89 \mathrm{Mgal} / \mathrm{d}$ (fig. 2).

${ }^{1}$ Water-withdrawal data are based on estimated or reported site-specific data and aggregated data, which are distributed to sources. For a full description of water-use estimate methodology, see "Data Collection" in Collier and Sargent (2018). Tabulation of numbers in text and tables may result in different totals because of rounding; nonrounded numbers are used for calculation of totals.

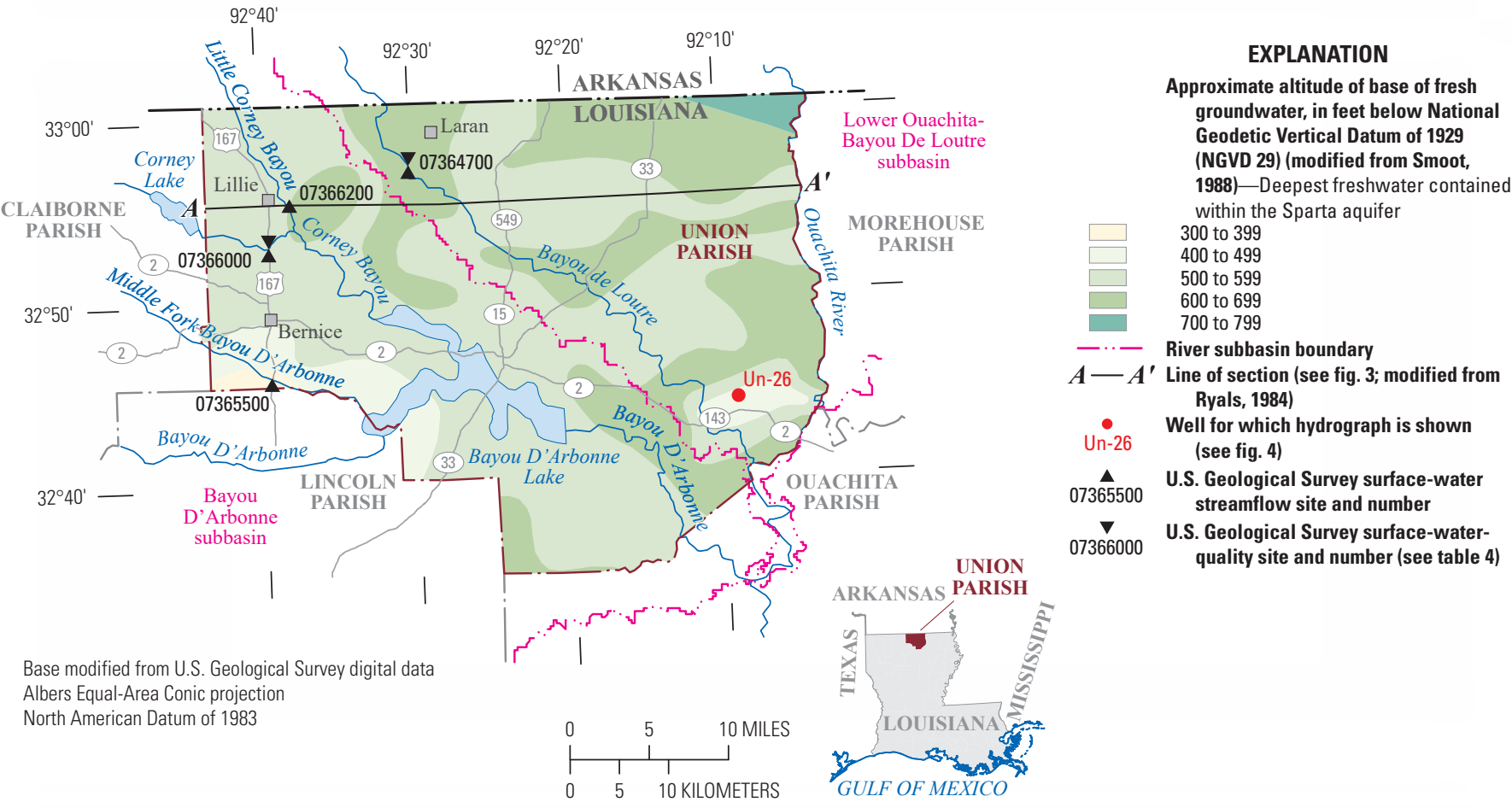

and alluvial aquifers overlie the Cook Mountain confining unit (figs. 1 and 3). The Cane River confining unit and Carrizo-Wilcox aquifer underlie the Sparta aquifer throughout the parish but only contain saltwater. The altitude of the base of fresh groundwater (water with a chloride concentration of 250 milligrams per liter $[\mathrm{mg} / \mathrm{L}]$ or less) within the Sparta aquifer ranges from about 500 feet (ft) below the National Geodetic Vertical Datum of 1929 (NGVD 29) in northwestern Union Parish to about $600 \mathrm{ft}$ below NGVD 29 towards the east-southeast (Smoot, 1988). 
Table 1. Water withdrawals, in million gallons per day, by source in Union Parish, Louisiana, 2014 (Collier, 2018).

$[<$, less than $]$

\begin{tabular}{lcc}
\hline \multicolumn{1}{c}{$\begin{array}{c}\text { Aquifer or } \\
\text { surface-water body }\end{array}$} & Groundwater & Surface water \\
\hline Sparta aquifer & 4.64 & \\
Cockfield aquifer & 0.05 & \\
Upland terrace aquifer & 0.01 & \\
Mississippi River & $<0.01$ & 0.18 \\
$\quad$ alluvial aquifer & & $\mathbf{0 . 1 8}$ \\
Miscellaneous streams & & \\
\cline { 2 - 3 } Total & $\mathbf{4 . 7 0}$ & \\
\hline
\end{tabular}

Table 2. Water withdrawals, in million gallons per day, by use category in Union Parish, Louisiana, 2014 (Collier, 2018).

$[<$, less than $]$

\begin{tabular}{lccc}
\hline \multicolumn{1}{c}{ Use category } & Groundwater & Surface water & Total \\
\hline Public supply & 4.36 & 0.00 & 4.36 \\
Industrial & 0.10 & 0.00 & 0.10 \\
Rural domestic & 0.19 & 0.00 & 0.19 \\
Livestock & 0.04 & 0.18 & 0.22 \\
Rice irrigation & 0.00 & 0.00 & 0.00 \\
General irrigation & 0.00 & $<0.01$ & 0.00 \\
\cline { 2 - 4 } Total & $\mathbf{4 . 7 0}$ & $\mathbf{0 . 1 8}$ & $\mathbf{4 . 8 8}$ \\
\hline
\end{tabular}

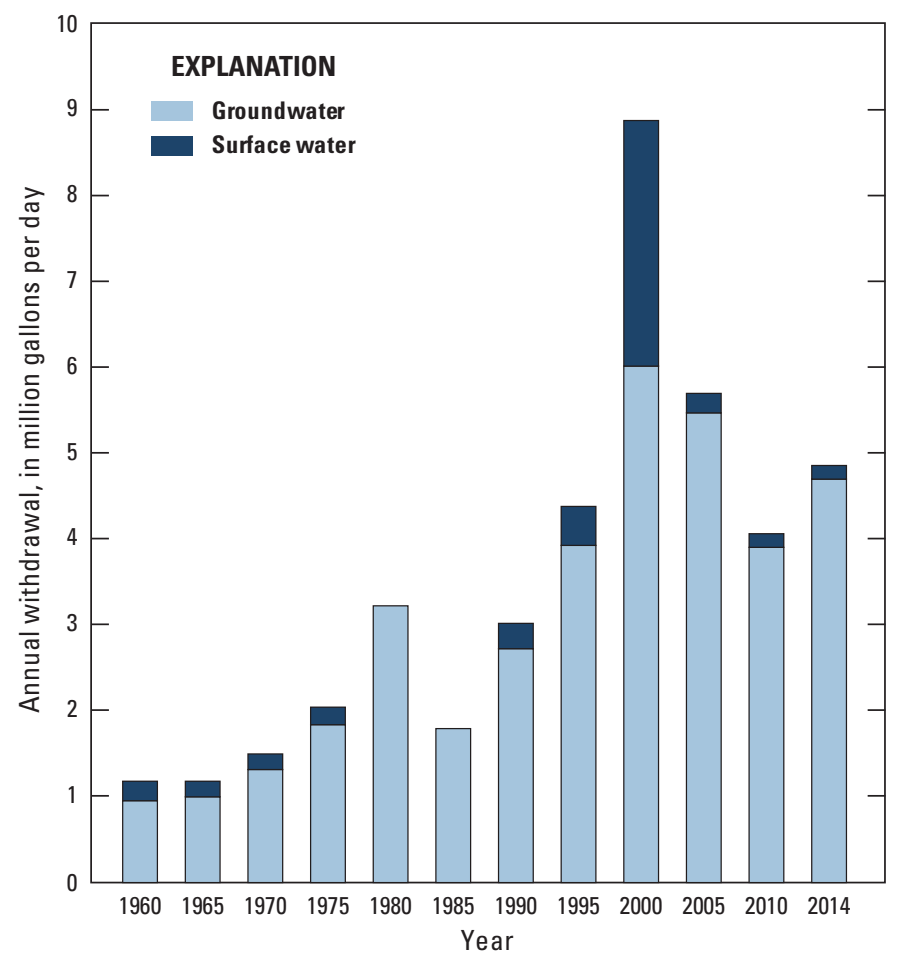

Figure 2. Water withdrawals in Union Parish, Louisiana, 19602014 (U.S. Geological Survey, 2016; Collier 2018).

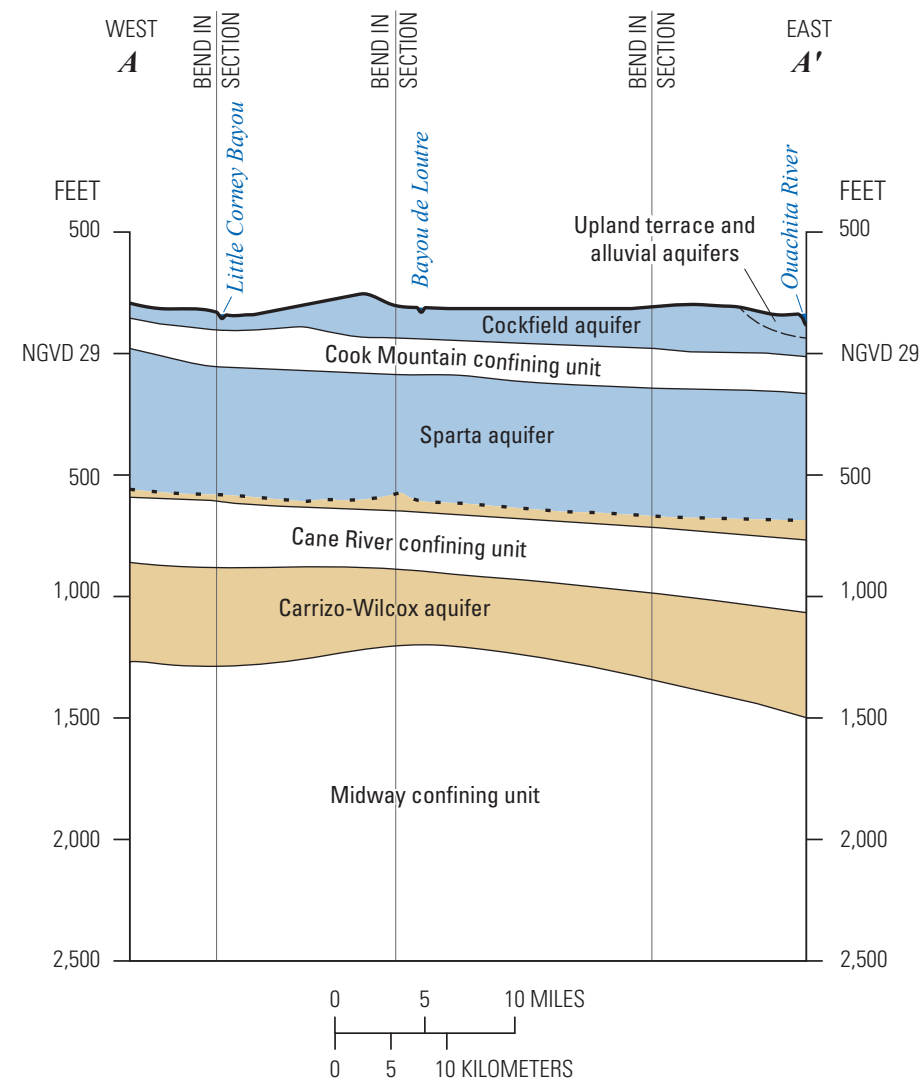

VERTICAL SCALE GREATLY EXAGGERATED

EXPLANATION

Hydrogeologic unit (modified from Ryals, 1984)

Aquifer containing freshwater-Freshwater

contains a chloride concentration of

250 milligrams per liter or less

Aquifer containing saltwater

Confining unit

Hydrogeologic contact (modified from Ryals,

1984) - Separates hydrogeologic units.

Dashed where approximately located

. - Approximate freshwater/saltwater interface

(modified from Ryals, 1984, and Smoot, 1988)

NGVD 29, National Geodetic Vertical Datum of 1929

Figure 3. Idealized west-to-east hydrogeologic section through Union Parish, Louisiana, showing aquifer and confining unit intervals (individual sand and clay layers not shown). Trace of section shown on figure 1.

\section{Sparta Aquifer}

The Sparta aquifer provided more than 98 percent of all groundwater withdrawn in Union Parish in 2014. The aquifer extends across all of Union Parish and is part of a large regional aquifer that is present in several States. The Sparta aquifer is composed of fine to medium sand with thin layers of clay and lignite (Payne, 1968; Snider and others, 1972). The thickness of the Sparta aquifer ranges from about $400 \mathrm{ft}$ in much of northwestern and north-central Union Parish to about $800 \mathrm{ft}$ in the southeast. The altitude of the base of the aquifer ranges from $600 \mathrm{ft}$ below NGVD 29 in the west to $800 \mathrm{ft}$ below NGVD 29 in the east, and most of the aquifer contains freshwater. The transition to saltwater is only marginally present along the eastern border of the parish and begins at about $750 \mathrm{ft}$ below NGVD 29 (Snider and others, 1972; Ryals, 1984). 
The primary source of recharge for the Sparta aquifer is the infiltration of precipitation in the outcrop areas (Brantly and others, 2002). Recharge also occurs by leakage from overlying rivers and aquifers. Groundwater generally moves towards the central and southeastern parts of the parish, towards Ouachita Parish (McGee and Brantly, 2015). Groundwater discharges through leakage into the other aquifers and confining units above and below the Sparta aquifer and through well withdrawals (Payne, 1968).

In 2012, altitudes of water levels in wells screened in the Sparta aquifer ranged from about $20 \mathrm{ft}$ below NGVD 29 in the northern part of the parish to deeper than $120 \mathrm{ft}$ below NGVD 29 in the south-central part of the parish (McGee and Brantly, 2015). Water levels in the Sparta aquifer at well Un-26, located in the southeast corner of Union Parish (figs. 1 and 4), declined by more than $50 \mathrm{ft}$ from 1957 to 2003, but have rebounded by about $12 \mathrm{ft}$ between 2004 and 2016. The recovery is likely a result from groundwater conservation efforts in south-central Arkansas (Freiwald and Johnson, 2007).

State well-registration records listed 183 active water wells screened in the Sparta aquifer in Union Parish in 2017: 72 public supply wells, 62 irrigation wells, 33 domestic wells, and 16 industrial wells. Well depths ranged from 82 to $812 \mathrm{ft}$ below land surface, and reported yields ranged from 10 to 930 gallons per minute (gal/min) (Louisiana Department of Natural Resources, 2017). In 2014, about $4.64 \mathrm{Mgal} / \mathrm{d}$ were withdrawn from the Sparta aquifer: $4.36 \mathrm{Mgal} / \mathrm{d}$ for public supply, $0.13 \mathrm{Mgal} / \mathrm{d}$ for rural domestic, $0.10 \mathrm{Mgal} / \mathrm{d}$ for industry, and $0.04 \mathrm{Mgal} / \mathrm{d}$ for livestock (Collier, 2018).

\section{Cockfield Aquifer}

The Cockfield aquifer underlies much of Union Parish and provides fresh groundwater to shallow domestic and irrigation wells. The aquifer contains mostly fine to medium sand with small layers of silt, siltstone, sandstone, and ironstone (Snider and others, 1972). Aquifer thickness ranges from 0 to $200 \mathrm{ft}$ across the entire parish, becoming increasingly thin and then absent in the eastern and southeastern parts of the parish. The altitude of the base of the aquifer ranges from about $100 \mathrm{ft}$ above NGVD 29 in western Union Parish to $100 \mathrm{ft}$ below NGVD 29 towards the east (Ryals, 1984).

The primary source of recharge for the Cockfield aquifer is the infiltration of precipitation. Groundwater generally moves downward to the underlying Cook Mountain confining unit or towards local streams where discharge results (fig. 3).

State well-registration records listed 37 active water wells screened in the Cockfield aquifer in Union Parish in 2017: 19 domestic wells, 17 irrigation wells, and 1 public-supply well. Depths of these wells ranged from 25 to $220 \mathrm{ft}$ below land surface, and reported yields ranged from 10 to $125 \mathrm{gal} / \mathrm{min}$ (Louisiana Department of Natural Resources, 2017). In 2014, about $0.05 \mathrm{Mgal} / \mathrm{d}$ were withdrawn from the Cockfield aquifer, all of which was withdrawn for rural domestic use (Collier, 2018).

\section{Upland Terrace and Alluvial Aquifers}

The Upland terrace and alluvial aquifers are the sand and gravel component of the terrace and alluvial deposits and are present in limited areas of Union Parish along the eastern border (fig. 3). Groundwater in the Upland terrace aquifer moves laterally to the alluvial aquifers and downward into the underlying units (Snider and others, 1972).

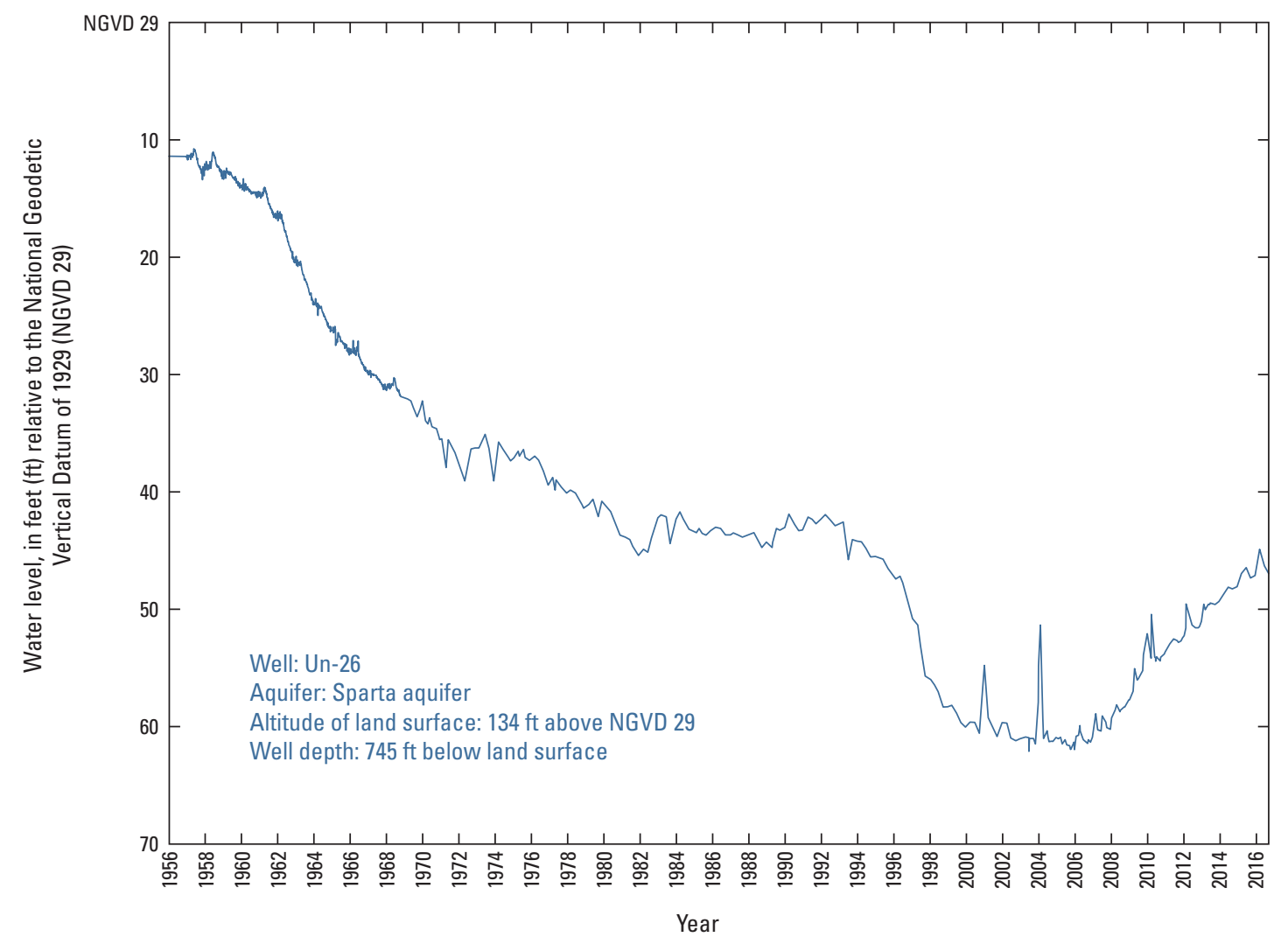

Figure 4. Water levels in well Un-26 screened in the Sparta aquifer in Union Parish, Louisiana (see figure 1 for well location; U.S. Geological Survey, 2018). 
In 2017, State well-registration records for Union Parish listed six active water wells screened in the Upland terrace aquifer: five domestic wells and one industrial well. Depths of these wells ranged from 25 to $69 \mathrm{ft}$ below land surface. Records listed 11 active water wells screened in the alluvial aquifers: 1 public supply well, 4 irrigation wells, and 6 domestic wells. Depths of these wells ranged from 26 to $90 \mathrm{ft}$ below land surface, and reported yields ranged from 5 to $25 \mathrm{gal} / \mathrm{min}$ (Louisiana Department of Natural Resources, 2017). In 2014, the Upland terrace aquifer and the alluvial aquifers each withdrew about $0.01 \mathrm{Mgal} / \mathrm{d}$ for domestic purposes (Collier, 2018).

\section{Groundwater Quality}

Groundwater samples were collected during 1905-2016 from 108 wells screened in the Sparta aquifer and during 1968-2014 from 7 wells screened in the Cockfield aquifer as part of an ongoing program to monitor the State's groundwater resources. These samples had median values that are within the U.S. Environmental Protection Agency's Secondary Maximum
Contaminant Levels ${ }^{2}$ (SMCLs) for chloride, sulfate, iron, and manganese (table 3). The values for $\mathrm{pH}$ exceeded the SMCL of $6.5-8.5$ in 38 percent of samples from the Sparta aquifer and 71 percent of samples from the Cockfield aquifer. The median hardness values of $6 \mathrm{mg} / \mathrm{L}$ for the Sparta aquifer and $21 \mathrm{mg} / \mathrm{L}$ for the Cockfield aquifer were both within the soft ${ }^{3}$ range. Concentrations of dissolved solids exceeded the SMCL in more than 70 percent of samples in the Sparta aquifer, but all samples from the Cockfield aquifer had concentrations below the SMCL of $500 \mathrm{mg} / \mathrm{L}$.

\footnotetext{
${ }^{2}$ The SMCLs are Federal guidelines regarding cosmetic effects (such as tooth or skin discoloration), aesthetic effects (such as taste, odor, or color), or technical effects (such as damage to water equipment or reduced effectiveness of treatment for other contaminants) of potential constituents of drinking water. SMCLs were established as guidelines by the U.S. Environmental Protection Agency (2016)

${ }^{3}$ Hardness ranges, expressed as milligrams per liter of calcium carbonate, are as follows: 0-60, soft; 61-120, moderately hard; $121-180$, hard; greater than 180, very hard (Hem, 1985).
}

Table 3. Summary of selected water-quality characteristics for freshwater from 108 wells screened in the Sparta aquifer and 7 wells screened in the Cockfield aquifer in Union Parish, Louisiana (U.S. Geological Survey, 2018).

[Values are in milligrams per liter, except as noted. ${ }^{\circ} \mathrm{C}$, degrees Celsius; $\mu \mathrm{S} / \mathrm{cm}$, microsiemens per centimeter; $\mathrm{SU}$, standard unit; $\mathrm{CaCO}_{3}$, calcium carbonate; $\mu \mathrm{g} / \mathrm{L}$, micrograms per liter; SMCL, Secondary Maximum Contaminant Level established by the U.S. Environmental Protection Agency (2016); NA, not applicable]

\begin{tabular}{|c|c|c|c|c|c|c|c|c|c|c|c|}
\hline & $\begin{array}{c}\text { Temperature } \\
\left({ }^{\circ} \mathrm{C}\right)\end{array}$ & $\begin{array}{l}\text { Color, } \\
\text { (platinum } \\
\text { cobalt } \\
\text { units) }\end{array}$ & $\begin{array}{c}\text { Specific } \\
\text { conductance, } \\
\text { field } \\
(\mu \mathrm{S} / \mathrm{cm} \text { at } \\
\left.25^{\circ} \mathrm{C}\right)\end{array}$ & $\begin{array}{c}\text { Dis- } \\
\text { solved } \\
\text { oxygen }\end{array}$ & $\begin{array}{l}\text { pH, } \\
\text { field } \\
\text { (SU) }\end{array}$ & $\begin{array}{c}\text { Hardness } \\
\text { (as } \\
\mathrm{CaCO}_{3} \text { ) }\end{array}$ & $\begin{array}{c}\text { Chloride, } \\
\text { filtered } \\
\text { (as CI) }\end{array}$ & $\begin{array}{l}\text { Sulfate, } \\
\text { filtered } \\
\text { (as } \mathrm{SO}_{4} \text { ) }\end{array}$ & $\begin{array}{c}\text { Iron, } \\
\text { filtered } \\
\text { ( } \mu \mathrm{g} / \mathrm{L} \\
\text { as Fe) }\end{array}$ & $\begin{array}{c}\text { Manga- } \\
\text { nese, } \\
\text { filtered } \\
\text { ( } \mu \mathrm{g} / \mathrm{L} \text { as } \\
\mathrm{Mn})\end{array}$ & $\begin{array}{l}\text { Dis- } \\
\text { solved } \\
\text { solids, } \\
\text { filtered }\end{array}$ \\
\hline \multicolumn{12}{|c|}{ Sparta aquifer (1905-2016) } \\
\hline Median & 24.5 & 30 & 1,210 & 0.3 & 8.4 & 6 & 182 & 0.27 & 14 & 1.7 & 668.5 \\
\hline 10th percentile & 22.0 & 5 & 703 & 0.1 & 7.8 & 2 & 37.1 & 0 & 6.1 & 0.6 & 333.1 \\
\hline 90th percentile & 25.2 & 60 & 1,500 & 1.5 & 8.8 & 15 & 355 & 2.96 & 308 & 10 & 807.2 \\
\hline $\begin{array}{c}\text { Number of } \\
\text { samples }\end{array}$ & 142 & 103 & 167 & 56 & 140 & 197 & 240 & 147 & 113 & 83 & 138 \\
\hline $\begin{array}{l}\text { Percentage } \\
\text { of samples } \\
\text { that do not } \\
\text { exceed } \\
\text { SMCLs }\end{array}$ & NA & 33 & NA & NA & 62 & NA & 72 & 100 & 89 & 98 & 28 \\
\hline \multicolumn{12}{|c|}{ Cockfield aquifer (1968-2014) } \\
\hline Median & NA & 5 & 98 & NA & 5.9 & 21 & 12.5 & 0.4 & 70 & 16.2 & 86.5 \\
\hline 10th percentile & NA & 0 & 44.8 & NA & 5.5 & 9.4 & 1.9 & 0 & 8 & 10.8 & 39 \\
\hline 90th percentile & NA & 12 & 257 & NA & 7.5 & 39 & 19.8 & 2.8 & 232 & 41 & 145 \\
\hline $\begin{array}{c}\text { Number of } \\
\text { samples }\end{array}$ & 1 & 6 & 7 & 1 & 7 & 8 & 8 & 7 & 7 & 4 & 6 \\
\hline $\begin{array}{l}\text { Percentage } \\
\text { of samples } \\
\text { that do not } \\
\text { exceed } \\
\text { SMCLs }\end{array}$ & NA & 100 & NA & NA & 29 & NA & 100 & 100 & 100 & 100 & 100 \\
\hline SMCLs & NA & 15 & NA & NA & $6.5-8.5$ & NA & 250 & 250 & 300 & 50 & 500 \\
\hline
\end{tabular}




\section{Surface-Water Resources}

Surface-water resources in Union Parish are present in two drainage subbasins and generally flow towards the southeastern parts of the parish. The Bayou D'Arbonne subbasin (Hydrologic Unit Code [HUC] 08040206) drains the west-southwestern half of the parish, and the Lower Ouachita-Bayou De Loutre subbasin (HUC 08040202) drains the east-northeastern half of the parish (fig. 1) (U.S. Geological Survey [USGS], 2018). In 2014, $0.18 \mathrm{Mgal} / \mathrm{d}$ were withdrawn from miscellaneous streams in these subbasins for agricultural purposes, including about $0.18 \mathrm{Mgal} / \mathrm{d}$ for livestock and less than $0.01 \mathrm{Mgal} / \mathrm{d}$ for general irrigation (tables 1 and 2) (Collier, 2018).

\section{Bayou D'Arbonne Subbasin}

The Bayou D'Arbonne subbasin covers the southwestern half of Union Parish. Major streams in the subbasin in the parish include Corney Bayou, Bayou D'Arbonne, and Middle Fork Bayou D'Arbonne (fig. 1). The annual average streamflow during 1956-2018 was 203 cubic feet per second $\left(\mathrm{ft}^{3} / \mathrm{s}\right)$ at the Little Corney Bayou near Lillie (USGS site number 07366200; fig. 1).
During this same period, the highest monthly average streamflow was $392 \mathrm{ft}^{3} / \mathrm{s}$ in March and the lowest was $28 \mathrm{ft}^{3} / \mathrm{s}$ during August (USGS, 2018). During 1941-57, the average annual streamflow for Corney Bayou near Lillie (USGS site number 07366000) was $475 \mathrm{ft}^{3} / \mathrm{s}$ (USGS, 2018). During 1941-71, the average annual streamflow for Middle Fork Bayou D'Arbonne near Bernice (USGS site number 07365500), located on the parish's southwestern border with Lincoln Parish, was $215 \mathrm{ft}^{3} / \mathrm{s}$ (USGS, 2018).

\section{Lower Ouachita-Bayou De Loutre Subbasin}

The Lower Ouachita-Bayou De Loutre subbasin is present in the northeastern half of Union Parish. The Ouachita River is the primary stream draining the Lower Ouachita-Bayou De Loutre subbasin in Union Parish. The Ouachita River enters Louisiana from Arkansas, establishing the border between Union Parish and Morehouse Parish, flowing in a southerly direction along the entirety of Union Parish's eastern boundary. The average streamflow during 1956-77 was $185 \mathrm{ft}^{3} / \mathrm{s}$ at Bayou de Loutre near Laran (USGS site number 07364700; fig. 1). During this same period, the highest monthly average streamflow was $342 \mathrm{ft}^{3} / \mathrm{s}$ in April and the lowest was $38 \mathrm{ft}^{3} / \mathrm{s}$ during August (USGS, 2018).

Table 4. Summary of selected water-quality characteristics for samples from the Corney Bayou near Lillie and Bayou de Loutre near Laran, Louisiana (U.S. Geological Survey, 2018).

[Values are in milligrams per liter, except as noted. ${ }^{\circ} \mathrm{C}$, degrees Celsius; $\mu \mathrm{S} / \mathrm{cm}$, microsiemens per centimeter; $\mathrm{SU}$, standard unit; $\mathrm{CaCO}_{3}$, calcium carbonate; $\mu \mathrm{g} / \mathrm{L}$, micrograms per liter; NA, not applicable; SMCL, Secondary Maximum Contaminant Level established by the U.S. Environmental Protection Agency (2016)]

\begin{tabular}{|c|c|c|c|c|c|c|c|c|c|c|c|c|c|c|}
\hline & $\begin{array}{l}\text { Tem- } \\
\text { perature } \\
\left({ }^{\circ} \mathrm{C}\right)\end{array}$ & $\begin{array}{l}\text { Color } \\
\text { (platinum } \\
\text { cobalt } \\
\text { units) }\end{array}$ & $\begin{array}{c}\text { Specific } \\
\text { conduc- } \\
\text { tance, field } \\
(\mu \mathrm{S} / \mathrm{cm} \text { at } \\
\left.25^{\circ} \mathrm{C}\right)\end{array}$ & $\begin{array}{l}\text { Dis- } \\
\text { solved } \\
\text { oxygen }\end{array}$ & $\begin{array}{l}\mathrm{pH}, \\
\text { field } \\
\text { (SU) }\end{array}$ & $\begin{array}{l}\text { Hard- } \\
\text { ness (as } \\
\mathrm{CaCO}_{3} \text { ) }\end{array}$ & $\begin{array}{c}\text { Cal- } \\
\text { cium, } \\
\text { filtered } \\
\text { (as Ca) }\end{array}$ & $\begin{array}{l}\text { Mag- } \\
\text { nesium, } \\
\text { filtered } \\
\text { (as Mg) }\end{array}$ & $\begin{array}{l}\text { So- } \\
\text { dium, } \\
\text { filtered } \\
\text { (as Na) }\end{array}$ & $\begin{array}{l}\text { Chlo- } \\
\text { ride, } \\
\text { filtered } \\
\text { (as CI) }\end{array}$ & $\begin{array}{l}\text { Sulfate, } \\
\text { filtered } \\
\text { (as } \mathrm{SO}_{4} \text { ) }\end{array}$ & $\begin{array}{c}\text { Iron, } \\
\text { filtered, } \\
\text { in } \mu \mathrm{g} / \mathrm{L} \\
\text { (as Fe) }\end{array}$ & $\begin{array}{c}\text { Man- } \\
\text { ganese, } \\
\text { filtered, } \\
\text { in } \mu \mathrm{g} / \mathrm{L} \\
\text { (as } \mathrm{Mn} \text { ) }\end{array}$ & $\begin{array}{l}\text { Dis- } \\
\text { solved } \\
\text { solids, } \\
\text { filtered }\end{array}$ \\
\hline \multicolumn{15}{|c|}{ Corney Bayou near Lillie (1943-84) ${ }^{1}$} \\
\hline Median & 17.5 & 15 & 402 & 7.9 & 5.6 & 81 & 19 & 4 & 45 & 140 & 5 & 195 & 1,520 & 283 \\
\hline 10th percentile & 7.5 & 0 & 169 & 3.9 & 4.7 & 34 & 8 & 1.9 & 18 & 50 & 2 & 145 & 344 & 109 \\
\hline 90th percentile & 28 & 40 & 557 & 10.6 & 6.2 & 380 & 27 & 6 & 63 & 715 & 10 & 360 & 2,920 & 441 \\
\hline $\begin{array}{c}\text { Number of } \\
\text { samples }\end{array}$ & 101 & 109 & 61 & 19 & 109 & 116 & 60 & 60 & 60 & 116 & 111 & 6 & 4 & 76 \\
\hline $\begin{array}{l}\text { Percentage of } \\
\text { samples that } \\
\text { do not exceed } \\
\text { SMCLs }\end{array}$ & NA & 60 & NA & NA & 7.3 & NA & NA & NA & NA & 72 & 100 & 83 & 0 & 96 \\
\hline \multicolumn{15}{|c|}{ Bayou de Loutre near Laran $(1956-86)^{2}$} \\
\hline Median & 18.5 & 20 & 1,740 & 7.3 & 6.5 & 200 & 61 & 11 & 270 & 484 & 30 & 120 & 185 & 878 \\
\hline 10th percentile & 6.63 & 15 & 496 & 4.74 & 6 & 61 & 17 & 3.66 & 80.4 & 126.4 & 9.6 & 80 & 173 & 315 \\
\hline 90th percentile & 28.05 & 40 & 4,640 & 10.8 & 7.1 & 580 & 180 & 28 & 761.6 & 1,528 & 80.4 & 398 & 197 & 2,266 \\
\hline $\begin{array}{c}\text { Number of } \\
\text { samples }\end{array}$ & 60 & 61 & 77 & 13 & 77 & 77 & 77 & 77 & 69 & 77 & 77 & 5 & 2 & 49 \\
\hline $\begin{array}{l}\text { Percentage of } \\
\text { samples that } \\
\text { do not exceed } \\
\text { SMCLs }\end{array}$ & NA & 28 & NA & NA & 57 & NA & NA & NA & NA & 23 & 100 & 80 & 0 & 22 \\
\hline SMCLs & NA & 15 & NA & NA & $6.5-8.5$ & NA & NA & NA & NA & 250 & 250 & 300 & 50 & 500 \\
\hline
\end{tabular}




\section{Surface-Water Quality}

Water samples were collected from Corney Bayou near Lillie (USGS site number 07366000) during 1943-84 and Bayou de Loutre near Laran (USGS site number 07364700) during 1956-86 (fig. 1) as part of an ongoing program to monitor the State's surface-water resources. The results for the samples were generally within SMCLs for concentrations of sulfate and iron (table 4). The $\mathrm{pH}$ values for the surface-water samples were outside the SMCL range for about 93 percent of the samples for Corney Bayou and for 43 percent of the samples from Bayou de Loutre. Manganese concentrations exceeded the SMCL of 50 micrograms per liter in all samples collected from both streams. Median hardness values were within the moderately hard range at Corney Bayou and the very hard range at Bayou de Loutre. Median dissolved-oxygen concentration values were greater than $7 \mathrm{mg} / \mathrm{L}$ at both sites; $5 \mathrm{mg} / \mathrm{L}$ is considered the minimum value for a diverse population of fresh, warmwater biota, including sport fish (Louisiana Department of Environmental Quality, 2017). Median values for color were equal to the SMCL (15 platinum cobalt units) for samples from Corney Bayou and greater than the SMCL for samples from Bayou de Loutre.

\section{References Cited}

Brantly, J.A., Seanor, R.C., and McCoy, K.L., 2002, Louisiana groundwater map no. 13-Hydrogeology and potentiometric surface of the Sparta aquifer in northern Louisiana, October 1996: U.S. Geological Survey Water-Resources Investigations Report 02-4053, 3 sheets. [Also available at https://doi.org/10.3133/wri024053.]

Collier, A.L., 2018, Water withdrawals by source and category in Louisiana Parishes, 2014-2015: U.S. Geological Survey data release, https://doi.org/10.5066/F78051VM.

Collier, A.L., and Sargent, B.P., 2018, Water use in Louisiana, 2015: Louisiana Department of Transportation and Development Water Resources Special Report no. 18, 138 p.

Freiwald, D.A., and Johnson, S.F., 2007, Monitoring of Sparta aquifer recovery in southern Arkansas and northern Louisiana, 2003-07: U.S. Geological Survey Fact Sheet 2007-3102, 4 p. [Also available at https://doi.org/10.3133/fs20073102.]

Hem, J.D., 1985, Study and interpretation of the chemical characteristics of natural water (3d ed.): U.S. Geological Survey Water-Supply Paper 2254, 264 p., accessed February 20, 2013, at http://pubs.er.usgs.gov/publication/wsp2254.

Louisiana Department of Environmental Quality, 2017, Environmental Regulatory Code, Title 33, Part IX, Subpart 1: Baton Rouge, Louisiana Department of Environmental Quality, accessed September 10, 2019, at https://www.deq.louisiana.gov/assets/docs/ Water/33v09-201707WaterQuality.pdf.

Louisiana Department of Natural Resources, 2017, Strategic Online Natural Resources Information System (SONRIS): Louisiana Department of Natural Resources database, accessed June 12, 2017, at http://sonris.com/.

McGee, B.D., and Brantly, J.A., 2015, Potentiometric surface, 2012, and water-level differences, 2005-12, of the Sparta aquifer in northcentral Louisiana: U.S. Geological Survey Scientific Investigations Map 3313, 2 sheets, accessed January 23, 2017, at https://pubs. er.usgs.gov/publication/sim3313.
Payne, J.N., 1968, Hydrologic significance of the lithofacies of the Sparta Sand in Arkansas, Louisiana, Mississippi, and Texas: U.S. Geological Survey Professional Paper 569-A, 17 p.

Ryals, G.N., 1984, Regional geohydrology of the northern Louisiana salt-dome basin; Part II, Geohydrologic maps of the Tertiary aquifers and related confining layers: U.S. Geological Survey Water-Resources Investigations Report 83-4135, 6 p., 7 pls. [Also available at https://pubs.er.usgs.gov/publication/wri834135.]

Smoot, C.W., 1988, Louisiana hydrologic atlas map no. 3-Altitude of the base of freshwater in Louisiana: U.S. Geological Survey Water-Resources Investigations Report 86-4314, 1 sheet, accessed November 2, 2011, at https://pubs.er.usgs.gov/publication/ wri864314.

Snider, J.L., Calandro, A.J., and Shampine, W.J., 1972, Water resources of Union Parish, Louisiana: Department of Conservation, Louisiana Geological Survey, and Louisiana Department of Public Works Water Resources Bulletin no. 17, 68 p.

U.S. Environmental Protection Agency, 2016, Secondary Drinking Water Standards - Guidance for nuisance chemicals, accessed April 13, 2016, at https:/www.epa.gov/dwstandardsregulations/ secondary-drinking-water-standards-guidance-nuisance-chemicals.

U.S. Geological Survey [USGS], 2016, U.S. Geological Survey Water Resources Cooperative Program-Louisiana Water Use Program, accessed November 16, 2016, at https://la.water.usgs.gov/WaterUse/ default.asp.

U.S. Geological Survey [USGS], 2018, USGS water data for the Nation: U.S. Geological Survey National Water Information System database, accessed September 4, 2018, at https://doi.org/10.5066/ F7P55KJN.

This fact sheet has been prepared by the USGS, in cooperation with the Louisiana Department of Transportation and Development (DOTD), as part of a program to document water use, availability, and quality in the parishes of Louisiana. Information on the availability, past and current water use, use trends, and water quality from groundwater and surface-water sources in the parish is presented here. Previously published reports (see References Cited section) and data stored in the USGS National Water Information System (USGS, 2018) are the primary sources of the information presented here. Special thanks are given to Doug Taylor, Director, and Zahir "Bo" Bolourchi (retired), DOTD Cooperative Program with the USGS.

\section{By Angela L. Robinson}

\section{For additional information, contact:}

Director, USGS Lower Mississippi-Gulf Water Science Center 3535 S. Sherwood Forest Blvd., Suite 120

Baton Rouge, LA 70816

E-mail: gs-w-lmg_center_director@usgs.gov

Fax: (225) 298-5490

Telephone: (225) 298-5481

Home Page: http://la.water.usgs.gov 